\title{
Anna Kearney Guigné. The Forgotten Songs of the Newfoundland Outports: As Taken from Kenneth Peacock's Newfoundland Field Collection, 1951-1961. Mercury Series. Ottawa: Canadian Museum of History and University of Ottawa Press, 2016. ISBN 978-0-77662-384-9 (paperback), 978-0-77662-385-6
}

\section{Heather Sparling}

Volume 33, numéro 1, 2018

URI : https://id.erudit.org/iderudit/1055878ar

DOI : https://doi.org/10.7202/1055878ar

Aller au sommaire du numéro

Éditeur(s)

Faculty of Arts, Memorial University

ISSN

1719-1726 (imprimé)

1715-1430 (numérique)

Découvrir la revue

Citer ce compte rendu

Sparling, H. (2018). Compte rendu de [Anna Kearney Guigné. The Forgotten Songs of the Newfoundland Outports: As Taken from Kenneth Peacock's

Newfoundland Field Collection, 1951-1961. Mercury Series. Ottawa: Canadian

Museum of History and University of Ottawa Press, 2016. ISBN

978-0-77662-384-9 (paperback), 978-0-77662-385-6]. Newfoundland and

Labrador Studies, 33(1). https://doi.org/10.7202/1055878ar 
Anna Kearney Guigné. The Forgotten Songs of the Nerwfoundland Outports: As Taken from Kenneth Peacock's Nerwfoundland Field Collection, 1951-1961. Mercury Series. Ottawa: Canadian Museum of History and University of Ottawa Press, 2016. ISBN 978-0-77662384-9 (paperback), 978-0-77662-385-6 (PDF)

While dozens of Canadian folksong and traditional song collections were published in the first half of the twentieth century - especially collections from Atlantic Canada - it is relatively uncommon to find similar collections published in the present day. I was therefore delighted to learn of Anna Kearney Guigné's new book, The Forgotten Songs of the Nerwfoundland Outports, a collection of more than 100 songs from more than 60 singers collected by Kenneth Peacock in the mid-twentieth century.

With this book, Peacock's collection of Newfoundland folksongs, well documented in the three-volume Songs of the Nerwfoundland Outports (1965), is fleshed out. As Guigné points out, Peacock's earlier volumes have been an important resource for many scholars, teachers, and singers. It is useful to augment this resource with the addition of songs that Peacock initially did not feel warranted publication, or that he perhaps could not easily publish due to copyright considerations. Peacock's choices were dictated by the concerns of the day; today, more than 50 years after Outports was initially published, we have different interests and concerns that warrant the publication of a greater array of Peacock's collected songs. Guignés book offers a window on the variety of songs and song sources that flourished in early to mid-twentieth-century Newfoundland while making an important contribution to the understanding of flows between commercial music (broadsides, song publications, radio, recordings) and traditional folksong.

Scholars have long known that parlour, stage, and vaudevillian songs circulated orally in communities, and they often give examples. However, what's special about this book is that it shows just how much of a role these songs played in fairly isolated communities across Newfoundland. At the same time, they're heard alongside local songs and 
other orally transmitted ballads so that we get a clear picture of the range of song repertoire circulating in Newfoundland in the early to mid-twentieth century.

Provided with each song are: its various titles; a cross-reference to Peacock's original field recording (i.e., PEA number) or manuscript; the singer's name, location, and date of recording; musical notation and lyrics (sometimes two or more versions are provided); a cross-reference to the song's Roud number (referencing the Roud Folksong and Broadside Indexes); and often extensive notes about the song's history and its other sources and versions (archival, published, and recorded) elsewhere in North America, the UK, and Ireland. New Roud numbers have been assigned to 32 songs that had never before appeared in print. Twenty-six of Peacock's original field recordings can also be heard via the Museum of History's YouTube channel. However, while the composer's name and the song's date and place of composition (if known) appear in each song's research notes, I would have found this information more valuable as part of each song's header information.

A strength of this volume is its great variety of songs. Some began as stage songs and were vernacularized, entering oral tradition. Guigné explains how this may have occurred, tracing where or how particular songs may have come to be known in Newfoundland. Some songs began in Scotland, England, or especially Ireland and eventually came to Newfoundland. In some cases, these songs are no longer known abroad; their only known versions are in Newfoundland. Other songs are local compositions. Some songs in the collection were once popular but are rarely heard today, while others never seem to have been well known. Many (but not all) have been collected by other collectors, but often have not been previously published. The songs' subject matter is quite varied, including political matters (e.g., Newfoundland's entry into Confederation, Hitler), disaster ballads, religious songs, labour songs, and songs about work, animals, sports, and, of course, a large number about sentimental love. The songs are from singers located in all corners of Newfoundland. 
The songs appear in alphabetical order by title. Guigné explains that she didn't want to organize the songs by thematic category mostly because many could fit under more than one category. Where songs are known by more than one title, alternative titles are provided in the table of contents, and an index of first lines is also provided at the end of the book.

I am a great fan of Guignés careful, detailed, and thorough research, on full display in this volume. Guigné has an extensive knowledge of primary and secondary sources, illustrated in the thorough bibliography. The introduction is excellent: it is concise while providing appropriate information about Peacock's collecting activities and a history of "commercial" songs in Newfoundland (and their impact on "folk" singing). The extensive notes accompanying each song are, quite frankly, impressive.

Another strength of the book is the singer biographies at the end of the manuscript. Earlier song collections rarely offered more than the briefest of details about the singers from whom songs were collected. Guigné, by contrast, undertook considerable research, including archival, census, and field research, to discover as much as possible about the singers represented in this volume, as well as in Peacock's original Folksongs of the Nerwfoundland Outports.

This book is likely to appeal to scholars (particularly folklorists, ethnomusicologists, popular music scholars, historians, and Canadianists, among others), teachers wanting to integrate Canadian vernacular culture into their curricula (particularly music and social studies teachers), singers (both professional and amateur), and tourists (especially to Newfoundland). The excellent detail, research notes, and references to other published and recorded versions of each song will allow singers, teachers, and scholars to investigate particular songs more deeply, if desired. The Forgotten Songs of the Newfoundland Outports is an excellent resource for anyone interested in traditional songs from Canada.

Heather Sparling

Cape Breton University 